\title{
Fresh Parboiled Rice Hulls Serve as an Alternative to Perlite in Greenhouse Crop Substrates
}

\author{
Michael R. Evans ${ }^{1}$ and Maryanne Gachukia ${ }^{2}$ \\ Department of Horticulture, University of Arkansas, Fayetteville, AR 72701
}

\begin{abstract}
Additional index words. bedding plants, vegetable transplants, nitrogen depletion, Oryza sativa, Catharanthus roseus, Impatiens walleriana, Viola $\times$ wittrockiana, Lycopersicon esculentum, Pelargonium $\times$ hortorum
\end{abstract}

Abstract. Ten substrates were formulated by blending perlite or parboiled fresh rice hulls (PFH) at $20 \%, 30 \%, 40 \%, 50 \%$, or $60 \%$ (v/v) with sphagnum peat. After 6 weeks, $\mathbf{N H}_{4}^{+}$ concentrations were not significantly different among substrates containing perlite and those containing equivalent amounts of PFH. Nitrate concentrations were significantly higher in the $40 \%$ perlite substrate than in the $40 \%$ PFH substrate, but there were no significant differences in $\mathrm{NO}_{3}^{-}$concentrations among the remaining substrates containing equivalent amounts of PFH or perlite. When tomato (Lycopersicon esculentum Mill.) was grown in the substrates for 5 weeks, tissue $\mathbf{N}$ concentrations were not significantly different between equivalent perlite and PFH-containing substrates. Non-parboiled fresh rice hulls produced organically contained a higher number of viable weed seeds than non-parboiled fresh rice hulls produced conventionally. No weed seeds germinated in the PFH. 'Better Boy' tomato, 'Bonanza Yellow' marigold (Tagetes patula L. French M.), 'Orbit Cardinal' geranium (Pelargonium xhortorum L.H. Bailey), 'Cooler Blush' vinca (Catharanthus roseus L.G. Don), 'Dazzler Rose Star' impatiens (Impatiens walleriana Hook. f.), and 'Bingo Azure' pansy (Viola $\times$ wittrockiana Gams) were grown in sphagnum peat-based substrates containing perlite or PFH at $10 \%, 15 \%, 20 \%, 25 \%, 30 \%, 35 \%$, or $40 \%(\mathrm{v} / \mathrm{v})$. Dry root weights of vinca and geranium were not significantly different among plants grown in the substrates. Tomato plants grown in $10 \%, 15 \%, 25 \%, 30 \%$, and $35 \%$ PFH had significantly higher dry root weights than those grown in equivalent perlite-containing substrates. Impatiens grown in 35\% PFH had higher dry root weights than those grown in 35\% perlite. Marigold grown in $20 \%$ perlite had higher dry root weights than those grown in $20 \%$ PFH. However, there were no significant differences in impatiens or marigold dry root weights among the remaining substrates containing equivalent amounts of PFH or perlite. Dry root weights of pansy grown in $10 \%, 20 \%$ $25 \%, 35 \%$, and $40 \%$ perlite were not significantly different from those grown in equivalent PFH-containing substrates. Across substrates, root dry weights of impatiens, marigold, and pansy grown in perlite-containing substrates were not significantly different from those grown in PFH-containing substrates. No significant difference in dry shoot weights of vinca, geranium, impatiens, and marigold occurred between equivalent perlite and $\mathrm{PFH}$ containing substrates. Tomato plants grown in $20 \%$ to $40 \%$ perlite had significantly higher dry shoot weights than those grown in equivalent PFH-containing substrates. However, dry shoot weights of tomato grown in $10 \%$ to $15 \%$ perlite were not significantly different from those grown in equivalent PFH-containing substrates. Dry shoot weights of pansy grown in $10 \%, 25 \%, 30 \%, 35 \%$, and $40 \%$ perlite were not significantly different from those grown in equivalent PFH substrates.

Artificial substrates are commonly used in the production of containerized greenhouse and nursery crops (Bunt, 1988; Nelson, 1998). Substrates are formulated from various organic and inorganic components to provide suitable physical and chemical properties as required by the specific crop and growing conditions (Bunt, 1988). An important physical property of artificial substrates is air-filled pore space. Air-filled pores allow for drainage and gas exchange between the root environment and the outside atmosphere (Bunt, 1988). Various

Received for publication 25 July 2003. Accepted for publication 5 Dec. 2003. This project was supported by Riceland Foods, Stuttgart, Ark., and the Arkansas Agricultural Research and Extension Service.

${ }^{1}$ Associate Professor.

${ }^{2}$ Graduate Research Associate. materials are used to provide for air-filled pore space in artificial substrates, with the most common being perlite.

Perlite is an inorganic expanded aluminosilicate of volcanic origin (Nelson, 1998) and is produced by mining the ore, grinding the crude ore to the desired particle size, and heating it to temperatures of up to $982{ }^{\circ} \mathrm{C}$. Heating causes the ore to expand from 4 to 20 times its original volume, resulting in a lightweight, white, porous particle (Hanan, 1998). Because of the costs associated with mining, transportation, and heating, perlite is a relatively expensive substrate component. In addition to its cost, in its dry state perlite produces a siliceous dust that is classified as an eye and lung irritant. Other less-costly substrate components that are not irritants and could provide for air-filled pore space in the substrate would be beneficial to the horticulture industry.

Rice hulls are available in large volumes as a waste product of the rice milling industry. It was estimated that 34 million tons of fresh rice hulls were produced annually in the United States (Kamath and Proctor, 1998). Fresh rice hulls had a total pore space of $89 \%$, while that of coarse perlite $(6.0-8.0 \mathrm{~mm})$ was $74 \%$ and fine perlite (1.0-2.0 mm) was $76 \%$ (Hanan, 1998). Air-filled porosity of fresh rice hulls was $69 \%$, while that of perlite $(1.0-2.0 \mathrm{~mm})$ was $54 \%$. Thus, fresh rice hulls had a higher total and air-filled pore space than perlite, and could provide for drainage and air-filled pore space in the substrate. Since rice hulls are generally considered an agricultural waste, they potentially have a low market value and could be less expensive than perlite.

Although aged, carbonized, and composted rice hulls have been used to a limited extent as an alternative to sphagnum peat and composted barks (Cadell, 1988; Einert, 1972; Einert and Baker, 1973; Kampf and Jung, 1991; Laiche and Nash, 1990), fresh rice hulls have typically been avoided as a substrate component due to anecdotal claims that rice hulls cause nitrogen depletion. However, there are no data to support this claim. Additionally, fresh rice hulls have often been contaminated with rice seeds and thus present a weed problem for growers. However, parboiled fresh rice hulls ( $\mathrm{PFH}$ ) have been subjected to sterilizing temperatures and should not contain viable weed seeds.

Therefore, the objectives of this research were to: 1) determine if nitrogen depletion or weed seeds would present a problem for growers using $\mathrm{PFH}$ as a perlite replacement; and 2) evaluate plant growth in sphagnum peat-based substrates in which the perlite was replaced with PFH.

\section{Materials and Methods}

Experiment 1:Ammoniumand nitrate levels of perlite and parboiled rice hull-containing substrates. Parboiled fresh rice hulls (PFH) were obtained from Riceland Foods (Stuttgart, Ark.). Perlite and sphagnum peat were obtained from SunGro Horticulture (Bellevue, Wash.). Calcitic lime was added to the sphagnum peat to adjust the initial $\mathrm{pH}$ to $\approx 5.4$ prior to mixing of the substrates.

Ten substrates were formulated by blending perlite or $\mathrm{PFH}$ at $20 \%, 30 \%, 40 \%, 50 \%$, or $60 \%(\mathrm{v} / \mathrm{v})$ with the sphagnum peat. Substrates were placed into $10-\mathrm{cm}(600-\mathrm{mL})$ plastic containers and transferred to a glass-glazed greenhouse. Greenhouse air temperatures were maintained between 20 and $25^{\circ} \mathrm{C}$ and light levels ranged from 350 to $525 \mu \mathrm{mol} \cdot \mathrm{s}^{-1} \cdot \mathrm{m}^{-2}$ at 12:00 HR. Containers were irrigated with $60 \mathrm{~mL}$ of a solution containing $200 \mathrm{mg} \cdot \mathrm{L}^{-1}$ $\mathrm{N}$ using a $15 \mathrm{~N}-2.2 \mathrm{P}-12.5 \mathrm{~K}$ fertilizer [Excel 15-5-15 Cal Mag (Scotts, Marysville, Ohio)]. This water-soluble fertilizer contained $1.2 \%$ $\mathrm{N}-\mathrm{NH}_{4}{ }^{+}, 11.75 \% \mathrm{~N}^{-\mathrm{NO}_{3}}{ }^{-}$, and $2.05 \% \mathrm{~N}-$ $\mathrm{CO}\left(\mathrm{NH}_{2}\right)_{2}$. This volume of solution was used to maintain a moist substrate but to minimize leaching. Although substrates dried at different rates, all containers were irrigated at the same 
time and received the same number of irrigations. Irrigation occurred on average at 5-d intervals (eight irrigations during experiment) and the final irrigation was applied $6 \mathrm{~d}$ before substrate samples were taken. Three samples of each substrate were taken after 0 (initiation of experiment) and 6 weeks (termination of experiment) and $\mathrm{NH}_{4}{ }^{+}$and $\mathrm{NO}_{3}{ }^{-}$concentrations determined for each substrate.

Substrate $\mathrm{NH}_{4}^{+}$concentrations were determined using the nitroprusside-salicylate procedure (Wall et al., 1975), while $\mathrm{NO}_{3}^{-}$concentrations were determined using the copperized cadmium reduction procedure (Keeney and Nelson, 1982). An analysis of variance (ANOVA) was conducted to determine if significant differences in $\mathrm{NH}_{4}{ }^{+}$and $\mathrm{NO}_{3}{ }^{-}$concentrations occurred among the substrates. Where significant differences occurred, singledegree-of-freedom contrasts were conducted to determine if significant differences occurred among substrates containing equivalent amounts of $\mathrm{PFH}$ and perlite.

Experiment 2: Tissue nitrogen of tomato grown in perlite and parboiled fresh rice hull-containing substrates. Protocols and environmental conditions were as described for Experiment 1 except where indicated. Four-leaf (excluding cotyledons) plugs [seedlings in 288-cell plastic plug trays with $5 \mathrm{~mL}$ volume per plug cell] of 'Better Boy' tomato were transplanted into10-cm containers filled with the substrates described for Experiment 1. Irrigation occurred on average at 2-d intervals. Shoots were harvested after 5 weeks, dried, ashed, and total $\mathrm{N}$ determined using the nitration of salicylic acid method (Cataldo et al., 1975). An ANOVA was conducted to determine if significant differences in $\mathrm{NH}_{4}^{+}$ and $\mathrm{NO}_{3}{ }^{-}$concentrations occurred among the substrates. Where significant differences occurred, single-degree-of-freedom contrasts were conducted to determine if significant differences occurred between substrates containing equivalent amounts of $\mathrm{PFH}$ and perlite.

Experiment 3: Occurrence of weeds in nonparboiled and parboiled fresh rice hull products. Non-parboiled fresh rice hulls (FRH) and $\mathrm{PFH}$ from conventionally grown rice were obtained from Riceland Foods (Stuttgart, Ark.). Non-parboiled fresh rice hulls from organically grown rice $(\mathrm{ORH})$ were obtained from Lowell Farms (Beaumont, Texas). The three rice hull products were placed into $54 \mathrm{~cm} \times 27 \mathrm{~cm} \times 6$ $\mathrm{cm}$ plastic flats to a depth of $2.5 \mathrm{~cm}(3.6 \mathrm{~L}$ of rice hulls). Flats were placed into a glass-glazed greenhouse. Greenhouse air temperatures were maintained between 24 and $32^{\circ} \mathrm{C}$, and light levels ranged from 420 to $600 \mu \mathrm{mol} \cdot \mathrm{s}^{-1} \cdot \mathrm{m}^{-2}$ at 12:00 HR. The hulls were irrigated and covered with a double layer of cheesecloth to maintain a moist environment and prevent contamination by weed seeds from external sources. Flats were irrigated as required to keep the hulls moist and to allow any viable weed seeds to germinate. For each of the three rice hull products, five flats were included with a flat serving as a replication. Over 6 weeks, the number of weed seeds germinating in each flat were counted. An ANOVA and least significant difference
(LSD) mean separation test were conducted to determine if significant differences in weed numbers occurred among the three rice hull products.

Experiment 4: Growth of annual species in perlite and parboiled fresh rice hull containing substrates. All experimental protocol were as described for Experiment 1 except where indicated. Fourteen substrates were formulated by blending perlite or PFH at $10 \%, 15 \%, 20 \%$, $25 \%, 30 \%, 35 \%$, or $40 \%$ (v/v) with sphagnum peat. Four-leaf (excluding cotyledons) plugs of 'Better Boy' tomato and 'Bonanza Yellow' marigold, and six-leaf plugs of 'Orbit Cardinal' geranium, 'Cooler Blush' vinca, 'Dazzler Rose Star' impatiens, and 'Bingo Azure' pansy were transplanted into $10-\mathrm{cm}$ plastic containers filled with each of the test substrates.

Plants were placed into a glass-glazed greenhouse. Greenhouse air temperatures were maintained between 24 and $32^{\circ} \mathrm{C}$, and light levels ranged from 350 to $525 \mu \mathrm{mol} \cdot \mathrm{s}^{-1} \cdot \mathrm{m}^{-2}$ at 12:00 HR. Immediately after being placed into the greenhouse, all containers were drenched with $50 \mathrm{~mL}$ of $15 \%$ etridiazole and $25 \%$ thiophanate-methyl (Banrot ${ }^{\circledR}$; Scotts) fungicide at the recommended label rate. Plants were fertilized at each irrigation with a $200 \mathrm{mg} \cdot \mathrm{L}^{-1} \mathrm{~N}$ solution using $15 \mathrm{~N}-2.2 \mathrm{P}-12.5 \mathrm{~K}$ water-soluble fertilizer. Irrigation was conducted as required to maintain moist substrates.

The number of weeds germinating per container was recorded. After 5 weeks for tomato and marigold, and 8 weeks for vinca, impatiens, geranium and pansy, the experiment was terminated. Dry shoot and root weights were determined. The experimental design was a randomized complete block with eight blocks and each substrate appearing once in each block. The experiment was repeated, but no significant time interaction occurred so data were pooled across time. An ANOVA was conducted to determine if significant differences in weed number or plant growth occurred among the different substrates. Singledegree-of-freedom contrasts were conducted to determine significant differences between substrates containing equivalent volumes of perlite and $\mathrm{PFH}$.

\section{Results and Discussion}

Experiment 1: Ammonium and nitrate levels of perlite and parboiled rice hullcontaining substrates. At the initiation of the experiment, $\mathrm{NH}_{4}{ }^{+}$and $\mathrm{NO}_{3}{ }^{-}$concentrations in the substrates ranged from 9.7 to $12.3 \mathrm{mg} \cdot \mathrm{L}^{-1}$ and 2.0 to $5.7 \mathrm{mg} \cdot \mathrm{L}^{-1}$, respectively (data not shown), and were not significantly different among substrates containing perlite and those containing equivalent amounts of PFH. After 6 weeks, $\mathrm{NH}_{4}{ }^{+}$and $\mathrm{NO}_{3}{ }^{-}$concentrations in the substrates ranged from 7.7 to $10.3 \mathrm{mg} \cdot \mathrm{L}^{-1}$ and 26.0 to $50.7 \mathrm{mg} \cdot \mathrm{L}^{-1}$, respectively (data not shown). Ammonium concentrations were not significantly different among substrates containing perlite and those containing equivalent amounts of PFH. Nitrate concentrations were significantly higher in the substrate containing $40 \%$ perlite than the substrate containing $40 \% \mathrm{PFH}$. However, there were no significant differences in $\mathrm{NO}_{3}{ }^{-}$concentrations between substrates containing $20 \%, 30 \%, 50 \%$, or $60 \%$ perlite and those containing equivalent amounts of PFH. Across all substrates, no significant difference in $\mathrm{NH}_{4}{ }^{+}$or $\mathrm{NO}_{3}{ }^{-}$substrate concentrations occurred between perlite and equivalent PFH-containing substrates under the conditions of this experiment.

Only the contrast for substrate $\mathrm{NO}_{3}^{-}$concentration of $40 \%$ perlite vs. $40 \% \mathrm{PFH}$ was significant. Therefore, the significant difference between these two substrates may have been a data artifact.

Despite anecdotal reports of $\mathrm{N}$ depletion when fresh rice hulls were used in substrates, we found that under the conditions of this experiment, $\mathrm{N}$ depletion did not occur or occurred at too low a rate to significantly impact substrate $\mathrm{NH}_{4}{ }^{+}$or $\mathrm{NO}_{3}^{-}$concentrations. Rice hulls are high in lignin, cutin, and insoluble silica and low in cellulose (Juliano et al., 1987). They are known to decompose very slowly; therefore, it would not be expected that PFH would cause significant $\mathrm{N}$ depletion. Additionally, associated with the first stage of decomposition of rice hulls (i.e., producing aged hulls) is the oxidative discoloration ("browning") of the hulls. In this experiment, there was no visually apparent change in the color of the PFH. Therefore, $\mathrm{PFH}$ could be substituted for perlite in a substrate without significant $\mathrm{N}$ depletion occurring and without requiring changes to the mineral nutrition program.

Experiment 2: Tissue nitrogen of tomato grown in perlite and parboiled fresh rice hullcontaining substrates. When maintained in the greenhouse for 5 weeks, tomato tissue $\mathrm{N}$ concentrations ranged from $2.1 \%$ to $3.3 \%$ and were not significantly different between equivalent perlite and PFH-containing substrates (data not shown). Lee et al. (2000a) reported that when pepper (Capsicum annuum L.) seedlings were grown in a sphagnum peat-based substrate amended with fresh rice hulls, tissue $\mathrm{N}$ decreased as the amount of fresh rice hull in the substrate increased. When composted hulls were used, no decrease in tissue $\mathrm{N}$ was observed. The authors attributed the decrease in tissue $\mathrm{N}$ in fresh rice hull-containing substrates at least partially to $\mathrm{N}$ depletion. In our research, we found no significant reduction in tissue $\mathrm{N}$ when plants were grown in PFH-containing substrates as compared to equivalent perlitecontaining substrates. In examining the data presented by Lee et al. (2000a), tissue $\mathrm{N}$ of pepper grown in up to $50 \%$ fresh rice hulls was higher or similar to the tissue $\mathrm{N}$ of peppers grown in substrates containing equivalent amounts of composted hulls. Therefore, at rates of up to $50 \%$ fresh rice hulls, no evidence for $\mathrm{N}$ depletion by fresh rice hulls occurred. Above $50 \%$ fresh rice hulls, they found that pepper tissue $\mathrm{N}$ decreased and was less than that for peppers grown in substrates containing equivalent levels of composted hulls. However, the differences in tissue $\mathrm{N}$ may not have been due to $\mathrm{N}$ depletion by fresh rice hulls but may have been due to changes in substrate physical properties. Regardless, the results from Lee et al. (2000a) concur with our results and support our findings that PFH can be used as a perlite 
substitute at rates of up to at least $40 \%(\mathrm{v} / \mathrm{v})$ without impacting plant tissue $\mathrm{N}$.

Experiment 3: Occurrence of weeds in nonparboiled and parboiled fresh rice hull products. Nonparboiled fresh rice hulls produced conventionally had an average of 0.8 weeds per $3.6 \mathrm{~L}$ of rice hulls, while ORH had 12.9 weeds per $3.6 \mathrm{~L}$ of rice hulls and was significantly higher than for conventionally grown rice hulls (data not shown). No weed seeds germinated in the PFH.

Both nonparboiled rice hull products contained viable weed seeds. All weeds in conventional hulls germinated from rice seeds remaining in the hulls after milling. Rice hulls from organically grown rice contained a variety of weeds including both monocotyledonous and dicotyledonous species. The differences could likely be attributed to the production techniques that avoid the use of herbicides and allow higher levels of weeds in the field under organic rice production. These weed seeds would also be harvested with the rice and some would therefore contaminate the rice hulls. Therefore, although weed seeds were present in rice hulls, parboiling was effective at killing the weed seeds; thus, PFH would provide a weed-free source of rice hulls for use in horticultural substrates.

Experiment 4: Growth of annual species in perlite and parboiled fresh rice hull containing substrates. The average number of weeds per container ranged from 0 to 0.13 and was not significantly different among the substrates (data not shown). Dry root weights of vinca and geranium were not significantly different among plants grown in the different substrates (Table 1). Dry root weights of tomato, impatiens, marigold, and pansy were significantly different among plants grown in the different substrates. Tomato plants grown in $10 \%, 15 \%$, $25 \%, 30 \%$, and $35 \% \mathrm{PFH}$ had significantly higher dry root weights than those grown in equivalent perlite-containing substrates. Across substrates, tomato plants grown in PFH-containing substrates had higher dry root weights than those grown in perlite-containing substrates. Impatiens plants grown in $35 \%$ perlite had higher dry root weights than those grown in $35 \% \mathrm{PFH}$, but dry root weights of impatiens grown in $10 \%, 15 \%, 20 \%, 25 \%$, $30 \%$, and $40 \%$ perlite were not significantly different from those grown in equivalent $\mathrm{PFH}$ substrates. Marigold plants grown in $20 \%$ perlite had higher dry root weights than those grown in substrate containing 20\% PFH, but dry root weights of marigold grown in $10 \%$, $15 \%, 25 \%, 30 \%, 35 \%$, and $40 \%$ perlite were not significantly different from those grown in equivalent PFH-containing substrates. Pansy plants grown in $15 \%$ perlite had higher dry root weights than those grown in $15 \% \mathrm{PFH}$, but pansy plants grown in $30 \%$ PFH had higher dry root weights than those grown in $30 \%$ perlite. Dry root weights of pansy grown in 10\%, $20 \%$ $25 \%, 35 \%$, and $40 \%$ perlite were not significantly different from those grown in equivalent PFH-containing substrates Across substrates, root dry weights of impatiens, marigold and pansy grown in perlite-containing substrates were not significantly different from those

Table 1. Dry root weight (mg) of tomato and marigold after 5 weeks, and vinca, geranium, impatiens, and pansy after 8 weeks when grown in peat-based substrates amended with perlite or fresh parboiled rice hulls.

\begin{tabular}{|c|c|c|c|c|c|c|c|c|c|}
\hline \multicolumn{10}{|c|}{ Substrate composition $(\% \mathrm{v} / \mathrm{v})^{2}$} \\
\hline \multicolumn{4}{|c|}{$\begin{array}{lll}\text { Peat } & \text { Perlite } & \text { Rice hull }\end{array}$} & Vinca & Geranium & Tomato & Impatiens & Marigold & Pansy \\
\hline 90 & 10 & 0 & & 1.6 & 2.1 & 0.4 & 0.6 & 1.0 & 0.6 \\
\hline 85 & 15 & 0 & & 1.6 & 2.0 & 0.4 & 0.7 & 0.8 & 0.6 \\
\hline 80 & 20 & 0 & & 1.5 & 2.1 & 0.5 & 0.5 & 1.0 & 0.6 \\
\hline 75 & 25 & 0 & & 1.4 & 2.1 & 0.4 & 0.6 & 1.0 & 0.7 \\
\hline 70 & 30 & 0 & & 1.6 & 2.2 & 0.4 & 0.5 & 0.8 & 0.6 \\
\hline 65 & 35 & 0 & & 1.7 & 1.8 & 0.5 & 0.5 & 0.9 & 0.6 \\
\hline 60 & 40 & 0 & & 1.3 & 2.0 & 0.5 & 0.5 & 0.9 & 0.6 \\
\hline 90 & 0 & 10 & & 1.3 & 2.0 & 0.6 & 0.6 & 1.0 & 0.6 \\
\hline 85 & 0 & 15 & & 1.5 & 2.2 & 0.6 & 0.7 & 1.0 & 0.4 \\
\hline 80 & 0 & 20 & & 1.5 & 2.0 & 0.5 & 0.6 & 0.7 & 0.5 \\
\hline 75 & 0 & 25 & & 1.5 & 2.1 & 0.5 & 0.7 & 1.1 & 0.6 \\
\hline 70 & 0 & 30 & & 1.5 & 2.2 & 0.6 & 0.6 & 0.8 & 0.8 \\
\hline 65 & 0 & 35 & & 1.7 & 2.1 & 0.6 & 0.6 & 0.9 & 0.8 \\
\hline 60 & 0 & 40 & & 1.4 & 2.2 & 0.4 & 0.6 & 1.0 & 0.8 \\
\hline \multicolumn{3}{|c|}{ Significance } & df & & & & & & \\
\hline \multirow{2}{*}{\multicolumn{2}{|c|}{$\begin{array}{l}\text { Substrate } \\
10 \% \text { Perlite vs. } 1\end{array}$}} & & 13 & NS & NS & **** & ** & * & ** \\
\hline \multirow{2}{*}{\multicolumn{3}{|c|}{$\begin{array}{l}10 \% \text { Perlite vs. } 10 \% \text { rice hull } \\
15 \% \text { Perlite vs. } 15 \% \text { rice hull }\end{array}$}} & 1 & NS & NS & *** & NS & NS & NS \\
\hline & & & 1 & NS & NS & $* * *$ & NS & NS & * \\
\hline \multicolumn{3}{|c|}{$20 \%$ Perlite vs. $20 \%$ rice hull } & 1 & NS & NS & NS & NS & $*$ & NS \\
\hline \multirow{2}{*}{\multicolumn{3}{|c|}{$\begin{array}{l}25 \% \text { Perlite vs. } 25 \% \text { rice hull } \\
30 \% \text { Perlite vs. } 30 \% \text { rice hull }\end{array}$}} & 1 & NS & NS & $* * *$ & NS & NS & NS \\
\hline & & & 1 & NS & NS & $* * *$ & NS & NS & * \\
\hline \multicolumn{3}{|c|}{$\begin{array}{l}30 \% \text { Perlite vs. } 30 \% \text { rice hull } \\
35 \% \text { Perlite vs. } 35 \% \text { rice hull }\end{array}$} & 1 & NS & NS & $*$ & ** & NS & NS \\
\hline \multicolumn{3}{|c|}{$40 \%$ Perlite vs. $40 \%$ rice hull } & 1 & NS & NS & NS & NS & NS & NS \\
\hline \multicolumn{3}{|c|}{ Perlite vs. rice hull } & 1 & NS & NS & $* *$ & NS & NS & NS \\
\hline
\end{tabular}

${ }^{2}$ Calcitic limestone was added to the peat to adjust $\mathrm{pH}$ to $\approx 5.4$ prior to use. Perlite was $6-8 \mathrm{~mm}$ horticultural grade and rice hulls were fresh parboiled rice hulls.

Ns, $, * * *, * * *$ Nonsignificant or significant at $P>\mathrm{F}=0.05,0.01$, or 0.001 , respectively.

Table 2. Dry shoot weight (mg) of tomato and marigold after 5 weeks, and vinca, geranium, impatiens, and pansy after 8 weeks grown in peat-based substrates amended with perlite or fresh parboiled rice hulls

\begin{tabular}{|c|c|c|c|c|c|c|c|c|c|}
\hline \multicolumn{10}{|c|}{ Substrate composition $(\% \mathrm{v} / \mathrm{v})^{2}$} \\
\hline Peat & Perlite & Rice hull & & Vinca & Geranium & Tomato & Impatiens & Marigold & Pansy \\
\hline 90 & 10 & 0 & & 7.9 & 8.3 & 1.4 & 3.8 & 4.9 & 4.5 \\
\hline 85 & 15 & 0 & & 8.5 & 8.5 & 1.3 & 4.0 & 5.4 & 4.1 \\
\hline 80 & 20 & 0 & & 7.9 & 7.8 & 1.4 & 3.6 & 5.4 & 4.3 \\
\hline 75 & 25 & 0 & & 6.7 & 7.9 & 1.3 & 3.7 & 5.3 & 4.8 \\
\hline 70 & 30 & 0 & & 8.1 & 7.4 & 1.2 & 2.9 & 5.0 & 4.2 \\
\hline 65 & 35 & 0 & & 8.7 & 6.3 & 1.4 & 2.9 & 4.6 & 3.9 \\
\hline 60 & 40 & 0 & & 6.8 & 7.0 & 1.1 & 3.0 & 5.4 & 4.1 \\
\hline 90 & 0 & 10 & & 7.0 & 7.8 & 1.3 & 3.9 & 5.9 & 3.8 \\
\hline 85 & 0 & 15 & & 7.9 & 7.8 & 1.3 & 3.7 & 5.4 & 2.5 \\
\hline 80 & 0 & 20 & & 8.5 & 7.2 & 1.1 & 3.3 & 4.8 & 3.2 \\
\hline 75 & 0 & 25 & & 7.3 & 7.5 & 0.8 & 3.7 & 5.1 & 3.9 \\
\hline 70 & 0 & 30 & & 7.3 & 7.5 & 0.8 & 3.3 & 4.8 & 4.5 \\
\hline 65 & 0 & 35 & & 7.5 & 6.9 & 0.8 & 3.4 & 4.9 & 4.1 \\
\hline 60 & 0 & 40 & & 6.4 & 6.9 & 0.7 & 2.5 & 4.9 & 3.8 \\
\hline \multicolumn{3}{|c|}{ Significance } & df & & & & & & \\
\hline \multicolumn{2}{|c|}{ Substrate } & & 13 & $* * *$ & ** & $* * *$ & ** & $* * *$ & $* * *$ \\
\hline \multicolumn{3}{|c|}{$10 \%$ Perlite vs. $10 \%$ rice hull } & 1 & NS & NS & NS & NS & NS & NS \\
\hline \multicolumn{3}{|c|}{$15 \%$ Perlite vs. $15 \%$ rice hull } & 1 & NS & NS & NS & NS & NS & ** \\
\hline \multicolumn{3}{|c|}{$20 \%$ Perlite vs. $20 \%$ rice hull } & 1 & NS & NS & $* *$ & NS & NS & * \\
\hline \multirow{2}{*}{\multicolumn{3}{|c|}{$\begin{array}{l}25 \% \text { Perlite vs. } 25 \% \text { rice hull } \\
30 \% \text { Perlite vs. } 30 \% \text { rice hull }\end{array}$}} & 1 & NS & NS & $* * *$ & NS & NS & NS \\
\hline \multirow{2}{*}{\multicolumn{3}{|c|}{$\begin{array}{l}30 \% \text { Perlite vs. } 30 \% \text { rice hull } \\
35 \% \text { Perlite vs. } 35 \% \text { rice hull }\end{array}$}} & 1 & NS & NS & $* * *$ & NS & NS & NS \\
\hline & & & 1 & NS & NS & $* * *$ & NS & NS & NS \\
\hline \multicolumn{3}{|c|}{$40 \%$ Perlite vs. $40 \%$ rice hull } & 1 & NS & NS & $* * *$ & NS & NS & NS \\
\hline \multicolumn{3}{|c|}{ Perlite vs. rice hull } & 1 & NS & NS & $*$ & & NS & NS \\
\hline
\end{tabular}

$\overline{{ }^{2} \text { Calcitic limestone was added to the peat to adjust } \mathrm{pH} \text { to } \approx 5.4 \text { prior to use. Perlite was } 6-8 \mathrm{~mm} \text { horticultural }}$ grade and rice hulls were fresh parboiled rice hulls.

Ns, $, * * *, * * * *$ Nonsignificant or significant at $P>\mathrm{F}=0.05,0.01$, or 0.001 , respectively.

grown in PFH-containing substrates.

Dry shoot weights of all species were significantly different among plants grown in the different substrates (Table 2). No significant difference in dry shoot weights of vinca, geranium, impatiens and marigold occurred between equivalent perlite and PFH-containing substrates. Tomato plants grown in $20 \%$ to $40 \%$ perlite had significantly higher dry shoot weights than those grown in equivalent PFH-containing substrates. However, dry shoot weights of tomato grown in $10 \%$ to $15 \%$ perlite were not significantly different from those grown in equivalent PFH-containing substrates. Across substrates, tomato grown in perlite substrates had higher dry shoot 
weights than those grown in PFH substrates. Pansy plants grown in $15 \%$ and $20 \%$ perlite had significantly higher dry shoot weights than those grown in equivalent PFH substrates. However, dry shoot weights of pansy grown in $10 \%, 25 \%, 30 \%, 35 \%$, and $40 \%$ perlite were not significantly different from those grown in equivalent PFH substrates. Overall, no significant difference occurred between dry shoot weights of pansy grown in perlite and PFH substrates.

Lee et al. (2000a, 2000b) reported reduced growth of pepper seedlings grown in substrates containing fresh rice hulls. However, we found that although some contrasts of equivalent perlite and $\mathrm{PFH}$-containing substrates were significant, in most cases, dry root and dry shoot weights of plants grown in perlite and $\mathrm{PFH}$-containing substrates were not significantly different. Where significant differences occurred, the difference was not high enough to be of commercial significance. Additionally, all plants produced in $\mathrm{PFH}$-containing substrates were of marketable quality. Therefore, based upon plant growth, PFH could be effectively used as a lower cost substitute for perlite in greenhouse substrates without a significant reduction in growth or plant quality.

\section{Literature Cited}

Bunt A.C. 1988. Media and mixes for container grown plants. Unwin Hyman Ltd., London.

Cataldo, D.A., M. Haroon, L.E. Schrader, and V.L. Young. 1975. Rapid colorimetric determination of nitrate in plant tissue by nitrate of salicylic acid. Commun. Soil Sci. Plant Anal. 6(1):81-93.

Cadell, M.L. 1988. Rice hull composting in Australia. Biocycle 29:49.

Einert, A.E. 1972. Performance of rice hulls as a growing media for pot lilies under three forcing systems. HortScience 7:60-61.

Einert, A.E. and A.C. Baker. 1973. Rice hulls as a growing medium component for cut tulips. J. Amer. Soc. Hort. Sci. 98:556-558.

Hanan J. J. 1998. Greenhouse-Advanced technology for protected horticulture. CRC Press. Boca Raton, Fla.

Juliano, B.O., C.C. Maningat, and C.G. Pascual. 1987. Properties of fraction of rice hull. Phytochemistry 26:3261-3263.

Kamath, S.R. and A. Proctor. 1998. Silica gel from rice hull ash: preparation and characterization. Cereal Chem. 75(4):484-487.

Kampf, A.N. and M. Jung. 1991. The use of carbon- ized rice hulls as an horticultural substrate. Acta Hort. 294:271-283.

Keeney, D.R. and D.W. Nelson. 1982. Nitrogen -Inorganic forms, p. 643-698. In: A.L. Page (ed.). Methods of soil analysis. Part 2, 2nd ed. Amer. Soc. Agron., Madison, Wis.

Laiche, A.J. and V.E. Nash. 1990. Evaluation of composted rice hulls and a lightweight clay aggregate as components of container-plant growth media. J. Environ. Hort. 8(1):14-18.

Lee, Ji-Won, Byoung-Yil Lee, Yong Beom Lee, and Ki-Sun Kim. 2000a. Growth and inorganic element contents of hot pepper seedlings in fresh and decomposed expanded rice hull-based substrates. J. Kor. Soc. Hort. Sci. 41(2):147-151.

Lee, Ji-Won, Byoung-Yil Lee, Kwang Yong Kim, and Sung Hee Kang. 2000b. Influence of $\mathrm{pH}$ and $\mathrm{NO}_{3} /$ $\mathrm{NH}_{4}$ ratio of nutrient solution and particle size distribution of rice hull on growth of hot pepper seedling in expanded rice hull-based substrates. J. Kor. Soc. Hort. Sci. 41(1):36-40.

Nelson, P.V. 1998. Greenhouse operation and management. 5th ed. Prentice Hall, Upper Saddle River, N.J.

Wall, L.L., C.W. Gehrke, T.E. Neuner, R.D Cathey, and P.R. Rexroad. 1975. Total protein nitrogen: Evaluation and comparison of four different methods. J. Assn. Official Anal. Chem. $58: 811-817$. 